\title{
Pengaruh Strategi Digital Marketing Terhadap Minat Beli Konsumen Di Era Pandemi Covid-19
}

\author{
Studi Kasus Pada Pengguna Marketplace Shopee di Provinsi Jawa Barat
}

\author{
Shofwan Azhar Sholihin, Mutiara Annissa Oktapiani \\ Institut Manajemen Koperasi Indonesia \\ shofwanas125@gmail.com \\ mutiaraaoktapiani95@gmail.com
}

\begin{abstract}
ABSTRAK
Shopee merupakan marketplace asal Singapura, dan mulai mengekspansi pasar Asia Tenggara sejak tahun 2015 termasuk ke Indonesia. Perubahan gaya hidup ditengah pandemi telah meningkatkan penggunaan media digital sebagai penunjang aktivitas berbelanja secara online. Jumlah penggunaan E-commerce mengalami peningkatan hingga 38,3\% selama masa pandemi Covid-19 yang dimulai sejak Januari hingga Juli 2020. Shopee yang berada dibawah naungan perusahaan SEA Group ini mampu mendapatkan perhatian konsumen di Indonesia. diketahui pada kuartal I-2020 Shopee mendapatkan kunjungan sebanyak 71,5 juta kunjungan dan pada kuarta II-2020 sebanyak 93,4 juta kunjungan dengan jumlah pesanan memasuki angka 260 juta pesanan atau meningkat sebesar 130\% dari sebelumya, Hal ini membuat Shopee kini telah menjadi salah satu marketplace yang paling sering digunakan untuk aktivitas belanja online Tujuan dari penelitian ini adalah untuk mengetahui apa strategi digital marketing yang dilakukan oleh Shopee, dan bagaimana pengaruhnya terhadap minat beli konsumen khususnya yang ada di Provinsi Jawa Barat saat terjadi pandemi Covid-19, serta upaya apa yang dapat dilakukan oleh Shopee untuk meningkatkan strategi digital marketing mereka. Berdasarkan hasil dari penelitian diketahui bahwa terdapat 3 strategi digital marketing yang dilakukan oleh Shopee yaitu teknik pemasaran yang sesuai dengan trend, memaksimalkan media digital sebagai tempat promosi, dan menerapkan bauran pemasaran 4C yang mana telah mempengaruhi minat beli konsumen sebesar 51,50\% dan sisanya 48,50\% dipengaruhi oleh faktor lain yang tidak diteliti dalam penelitian ini seperti kebutuhan, produk berkualitas, dan sebagainya.
\end{abstract}

Kata Kunci: Strategi Digital Marketing, Minat Beli Konsumen, Shopee

\begin{abstract}
Shopee is a marketplace from Singapore, and has started to expand the Southeast Asian market since 2015 including Indonesia. Lifestyle changes amid the pandemic have increased the use of digital media to support online shopping activities. The number of E-commerce usage has increased by $38.3 \%$ during the Covid-19 pandemic which started from January to July 2020. Shopee, which is under the auspices of the SEA Group company, is able to get the attention of consumers in Indonesia. It is known that in the first quarter of 2020 Shopee received 71.5 million visits and in the second quarter of 2020 there were 93.4 million visits with the number of orders entering the number of 260 million orders or an increase of $130 \%$ from the previous. The purpose of this study is to find out what digital marketing strategy is being carried out by Shopee, and how it affects consumer buying interest, especially in West Java Province during the Covid-19 pandemic, as well as what efforts can be made by Shopee to improve digital marketing strategies. they. Based on the results of the research, it is known that there are 3 digital marketing strategies carried out by Shopee, namely marketing techniques that are in accordance with the trend, maximizing digital media as a place of promotion, and implementing the $4 C$ marketing mix which has influenced consumer buying interest by $51.50 \%$ and the remaining 48. ,50\% is influenced by other factors not examined in this study such as needs, quality products, and so on.
\end{abstract}

Keyword: Strategi Digital Marketing, Minat Beli Konsumen, Shopee 


\section{PENDAHULUAN}

Pandemi Covid-19 yang terjadi saat ini telah menyebabkan segala aktivitas manusia menjadi terhambat. Penyebaran virus yang semakin massif disebabkan oleh adanya penularan lewat kontak antara satu orang dengan orang lain, sehingga pemerintah secara proaktif mengambil kebijakan memberlakukan social distancing. Sejak kemunculannya pada akhir tahun 2019 hingga saat ini, virus Covid-19 atau Coronavirus tidak hanya berdampak pada kesehatan manusia, namun berdampak juga pada sektor lain yaitu sektor ekonomi yang menyangkut bisnis di berbagai industri. Ada industri yang keberadaannya tiba-tiba melejit seperti platform digital dan kesehatan. Namun, banyak juga industri yang malah redup karena tidak mampu untuk beradaptasi dengan situasi krisis saat ini. Seiring dengan perkembangan teknologi yang semakin pesat, khususnya di abad ke-21 ini, menghadirkan satu inovasi dalam dunia bisnis khususnya pada bidang pemasaran yang disebut dengan digital marketing. Menurut Dave Chaffey (2008:399), "Internet marketing/digital marketing cenderung mengacu pada eksternal perspektif tentang bagaimana internet dapat digunakan bersama-sama dengan media tradisional untuk mendapatkan dan memberikan layanan kepada pelanggan”.

Penyebaran virus Covid-19 tidak bisa dipungkiri telah menjadikan perubahan pada gaya hidup masyarakat. Krisis global yang disebabkan oleh pandemi Coronavirus telah mendorong kehidupan manusia lebih jauh ke dunia digital. Jika sebelumnya pelaku bisnis dan pelanggan berinteraksi secara langsung pada tempat dan waktu yang sama, maka saat ini hal tersebut tidak bisa lagi dilakukan. Dikutip dari laman Tirto.id, jumlah penggunaan E-commerce mengalami peningkatan hingga $38,3 \%$ selama masa pandemi Covid-19 yang dimulai sejak Januari hingga Juli 2020. Data tersebut sesuai dengan catatan yang dilaporkan Exabytes, yang merupakan perusahaan penyedia layanan hosting di Indonesia melalui keterangan tertulis yang diterima Tirto.id, Selasa (25/08/2020).

Peningkatan penggunaan E-commerce ini tidak lain disebabkan oleh adanya perubahan perilaku konsumen untuk memenuhi kebutuhan sehariharinya dengan berbelanja online terutama pada masa Pembatasan Sosial Berskala Besar (PSBB). Masih bersumber dari survey yang dilakukan oleh Exabytes melalui laman Tirto.id dikutip dari Sea Insight yang menemukan bahwa $45 \%$ pelaku usaha bisnis lebih aktif berjualan di E- commerce pada saat pandemi. Dari data tersebut kita dapat menyimpulkan bahwa media online dapat menjadi solusi bagi para pelaku bisnis untuk tetap mempertahankan usahanya di tengah pandemi Covid-19. Berkembangnya industri ekonomi digital pada saat ini, telah membuat beberapa e-commerce berhasil mempertahankan eksistensinya di tengah pandemi Covid-19. Beberapa faktor dapat mempengaruhi minat beli konsumen, misalnya kombinasi merek yang menggambarkan bagaimana suatu simbol perusahaan, merek, maupun keragaman produk, komunikasi dengan pelanggan hingga bagaimana cara memanfaatkan media digital sebagai advertising place, seperti Shopee yang telah menjadi e-commerce dengan pengunjung situs bulanan terbesar di Indonesia.

Shopee merupakan marketplace asal Singapura, dan mulai mengekspansi pasar Asia Tenggara sejak tahun 2015 termasuk ke Indonesia. Selanjutnya pada perjalanannya, empat tahun kemudian Shopee berhasil menjadi marketplace terbesar ketiga di Indonesia. Kunjungan bulanan Shopee mencapai 74.995.300 kunjungan selama 4 tahun terakhir. Marketplace yang berada dibawah SEA Group ini mampu mendapatkan perhatian konsumen di Indonesia karena kampanye-kampanye yang dilakukannya yang melibatkan selebritas internasional seperti Blackpink. Dikutip dari laman Databoks, data iPrice menunjukan, Shopee mendapatkan kunjungan sebanyak 71,5 juta kunjungan selama kuartal I-2020. Lalu disusul oleh Tokopedia dan Bukalapak dengan masing-masing sebanyak 69,8 juta dan 37,6 juta kunjungan. Dengan berbagai kampanye yang dilakukan oleh Shopee jumlah pesanan bruto yang masuk ke platform Shopee meningkat dari

$150,1 \%$ menjadi $615,9 \%$ pada kuartal II tahun 2020, ini berdasarkan operasional Shopee di Indonesia, Malaysia, Filipina, Singapura, Thailand, Vietnam, Taiwan, dan Brazil. Di Indonesia sendiri, jumlah pesanan selama periode April-Juni 2020 memasuki angka 260 juta pesanan, dengan transaksi per hari rata-rata 2,8 juta lebih atau meningkat sekitar

130\%. Meski transaksinya melonjak, EBITDA Shopee mencatat selama pandemi yang disesuaikan negative sebesar US\$305,5 juta. Kerugian ini meningkat dari tahun lalu, yang hanya US\$248,3 juta saja.

Dikutip dari data yang dihimpun oleh iPrice, terdapat jumlah kunjungan pada masing-masing $e$ commerce pada tahun 2019 hingga pertengahan 
tahun 2020 pada lima e-commerce terbesar di Indonesia. Dari data ini dapat terlihat pertumbuhan pengunjung dari kurun waktu tersebut dan hubungannya dengan pandemi Covid-19 di Indonesia.

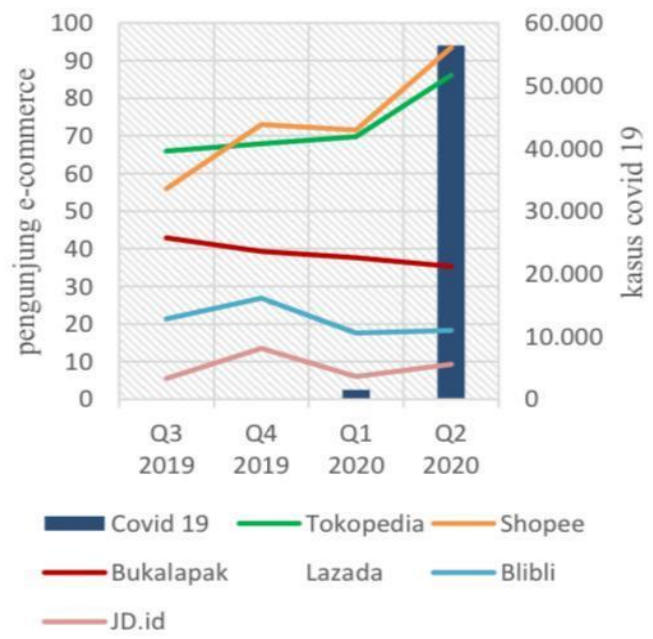

Sumber: iPrice

Gambar 1 Grafik visualisasi pertumbuhan pengunjung bulanan lima commerce terbesar di Indonesia dari kuartal keempat 2019 hingga kuartal kedua tahun 2020

Dari gambar 1, terlihat e-commerce Shopee dan Tokopedia terus bersaing mengalami lonjakan yang signifikan pada kuartal kedua di tahun 2020. Jika sebelumnya pada kuartal ketiga tahun 2019 Tokopedia di posisi pertama, namun pada kuartal keempat

2019 hingga kuartal kedua 2020 Shopee mampu merebut posisi tersebut. Selama pandemi Covid-19 berlangsung direktur Shopee Indonesia Handhika Jahja, mengkonfirmasi bahwa Shopee mencatat alami kenaikan transaksi 4 kali lipat pada puncak kampanye dibandingkan hari biasa di masa pandemi. Melihat fenomena tersebut, yaitu begitu tingginya antusias masyarakat dalam berbelanja online, maka peneliti tertarik untuk melakukan penelitian dengan judul "Pengaruh Strategi Digital Marketing Terhadap Minat Beli Konsumen di Era Pandemi Covid-19" studi kasus pada pengguna marketplace Shopee dengan menggunakan non probability quota sampling sebanyak 100 orang di Provinsi Jawa Barat.

\section{TINJAAN PUSTAKA}

1. Pendekatan Manajemen Pemasaran

Philip Kotler (2000:9) menyebutkan bahwa: "Pemasaran adalah suatu proses sosial dan manajerial yang di dalamnya individu dan kelompok mendapatkan apa yang mereka butuhkan dan inginkan dengan menciptakan, menawarkan, dan mempertukarkan produk yang bernilai dengan pihak lain".

Dalam pendapat lain Kotler dan Armstrong (2008:6) juga menyebutkan bahwa "Pemasaran adalah proses dimana perusahaan menciptakan nilai bagi konsumen sehingga dapat mengelola hubungan yang baik dengan konsumen, dengan tujuan menangkap nilai dari konsumen tersebut sebagai imbalan perusahaan".

Pada dasarnya, pengertian pemasaran tersebut menyatakan pemasaran bukan hanya sekedar tentang mengenalkan barang tetapi juga perusahaan harus mampu membuat komunikasi yang baik dengan konsumen sehingga dapat menciptakan hubungan timbal balik yang positif dan saling menguntungkan satu sama lain. Dari deskripsi diatas dapat ditarik kesimpulan bahwa pendekatan manajemen pemasaran merupakan cara yang terstruktur yang dapat dilakukan oleh pelaku usaha dalam menentukan target pasar untuk dapat mendelivery produk barang/jasa kepada konsumen yang tepat sehingga mendapatkan profit yang maksimal dengan cara yang efektif dan efisien.

\section{Pendekatan Strategi Pemasaran}

Strategi Pemasaran merupakan suatu tindakan pemasaran untuk mencapai tujuan perusahaan (Djaslim Saladin: 2002). Sedangkan menurut Tjiptono (2002:6) menjelaskan tentang strategi pemasaran sebagai berikut: "Strategi pemasaran adalah alat yang fundamental yang direncanakan untuk mencapai perusahaan dengan mengembangkan keunggulan bersaing yang berkesinambungan melalui pasar yang dimasuki dan program pemasaran yang digunakan untuk melayani pasar sasaran tersebut".

Terdapat empat konsep penting strategi pemasran, keempat konsep itu adalah: 
1) Market Segmentation. Perusahaan harus mengelompokan pasar yang terdiri dari berbagai macam pembeli yang sifatnya heterogen menjadi kelompok- kelompok kecil yang lebih homogen, agar mudah untuk ditembus.

2) Market Positioning. Dengan pemilihan pola pasar yang spesifik, maka perusahaan bisa mendapatkan kesempatan posisi yang kuat dibandingkan para pesaingnya.

3) Market Entry Strategy. Adalah cara yang digunakan perusahaan untuk mencapai segmen pasar yang telah dijadikan pasar sasaran penjualan.

4) Marketing Mix Strategy. Merupakan kumplan variable-variabel yang digunakan perusahaan agar dapat mempengaruhi tanggapan konsumennya. Variable-variabel ini ada 4P (Product, Price, Place, Promotion).

\section{Pendekatan Pemasaran Digital (Digital Marketing)}

Pemasaran digital ini dari tahun ke tahun berubah secara signifikan, khususnya pada era 4.0 (Marketing 4.0). "Marketing $\quad 4.0 \quad$ adalah pendekatan pemasaran yang menggabungkan interaksi online dan offline antara perusahaan dengan pelanggan" (Phillip Kotler 2017:43). Sedangkan menurut Caviello, Milley \& Marcolin (2001:26) "Digital marketing ialah penggunaan fasilitas internet dan penggunaan teknologi interaktif lain untuk membuat dan menghubungkan dialog antara perusahaan dan konsumen yang telah teridentifikasi". Menurut Philip Kotler (2017:46) dalam Marketing 4.0, bauran pemasaran 4P bisa dijabarkan kembali menjadi 4C yaitu:

\section{- Co-Creation (Menciptakan Bersama)}

Strategi baru ini dapat diterapkan perusahaan dengan melibatkan konsumen dalam pengembangan produk dari mulai terciptanya gagasan awal.

\section{- Currency (Mata Uang)}

Penetapan harga pada era digital juga menjadi pertimbangan yang harus diperhatikan, dari mulai penetapan harga standar hingga harga yang dinamis.

\section{- Communal Activation (Aktivasi Komunal)}

Membentuk saluran aktivasi komunal (distribusi dari rekan-ke-rekan) sangat dibutuhkan karena menyangkut kecepatan waktu dan ketersediaan produk demi terciptanya kepuasan pelanggan.

- Conversation (Percakapan)

Memungkinkan konsumen dapat melakukan evaluasi bersama konsumen lain, sehingga mungkin saja percakapan yang dilakukan konsumen tersebut menjadi bahan referensi bagi konsumen lain.

4. Pendekatan Strategi Pemasaran Digital (Digital Marketing)

Digital marketing adalah sebuah bentuk penerapan dari teknologi digital yang membentuk online channel ke pasar (berbentuk website, e-mail, dan media social lainnya) yang memberikan kontribusi terhadap kegiatan pemasaran sehingga bertujuan untuk mendapatkan keuntungan dan mempertahankan konsumen (Chaffey 2002:14). Ada tujuh strategi digital marketing yang sering digunakan, yaitu:

a. Website, memiliki peran dalam menunjukan profesionalisme perusahaan, dan membantu konsumen untuk mengetahui bisnis dari perusahaan yang bersangkutan.

b. Search Engine Marketing (SEM), Pemasaran mesin pencari merupakan bentuk pemasaran internet dengan melibatkan promosi situs web dengan meningkatkan visibilitasnya di halaman hasil mesin pencari terutama melalui iklan berbayar seperti Google.

c. Social Media Marketing (SMM), ialah bentuk pemasaran melalui media social dan situs web jaringan untuk mempromosikan produk dengan cara berbayar atau secara gratis.

d. Online advertising, pemasaran ini memanfaatkan internet sebagai media untuk menyampaikan iklan produk dalam bentuk promosi berbayar.

e. Email marketing merupakan saluran promosi yang memanfaatkan media digital surat elektronik (email) untuk mempromosikan produk atau layanan bisnis.

f. Video Marketing. Dengan menggunakan teknik ini perusahaan dapat menampilkan, menginformasikan, serta mempraktikan testimoni produk secara langsung kepada audiens.

g. Pemasaran afiliasi berarti bahwa perusahaan membangun jaringan dengan pihak lain untuk memasarkan produknya agar mencapai target pasar yang lebih luas. 


\section{Alur Kerja E-Commerce}

Electronic commerce atau e-commerce adalah bentuk aktivitas jual beli (perdagangan) melalui media elektronik, salah satunya adalah media internet. Adapun marketplace seperti Shopee merupakan salah satu model e-commerce. Sementara ada empat komponen penting didalam $e$ commerce, keempat komponen tersebut adalah sebagai berikut:

1) Penjual, atau seller ini merupakan pihak yang memiliki toko online atau sejumla pelaku usaha yang menjual produknya melalui platform $e$ commerce tersebut.

2) Konsumen, konsumen memiliki peran yang penting dalam dunia transaksi jual beli yang dilakukan secara online ataupun offline. Sehingga, keberadaan konsumen ini perlu diperhatikan, dan diberikan service yang baik.

3) Teknologi, elemen ini meliputi semua bentuk teknologi dan informasi yang digunakan dalam e-commerce. Seperti teknologi web, aplikasi mobile, keamanan transaksi, dukungan cloud computing, ERP, CRM, POS, dan sebagainya.

4) Jaringan komputer (internet), ketersediaan jaringan internet ini dapat memberikan kemudahan kepada siapa saja yang ingin melakukan bisnis, tanpa takut terbatasi waktu dan lokasi.

\section{Pendekatan Minat Beli Konsumen}

Menurut Kinnear dan Taylor (1995:306), "Minat beli adalah kecenderungan responden untuk bertindak sebelum keputusan membeli benarbenar dilaksanakan". Sedangkan menurut Kotler dan Keller (2009:15), mengatakan bahwa "Minat beli merupakan perilaku yang muncul sebagai respon terhadap objek yang menunjukan keinginan konsumen untuk melakukan pembelian". Menurut Ferdinand (2002:129) minat beli dapat diidentifikasi melalui indikator-indikator sebagai berikut:

Minat transaksional, yaitu situasi dimana seseorang cenderung untuk membeli produk yang diinginkannya.

Minat referensial, yaitu kecenderungan seseorang mereferensikan atau menyarankan produk tertentu kepada orang lain.

Minat preferensial, ialah minat seseorang yang memiliki preferensi utama pada produk tersebut. Preferensi ini hanya dapat digantikan apabila terjadi sesuatu pada produk preferensinya.
Minat eksploratif, minat ini menggambarkan perilaku individu yang selalu mencari informasi mengenai produk yang diminatinya dan untuk mendukung sifat-sifat positif dari produk tersebut.

\section{METODE PENELITIAN}

Penelitian ini menggunakan metode studi kasus (case study), yang merupakan salah satu metode penelitian deskriptif yang bertujuan untuk mempelajari latar belakang keadaan secara lebih mendalam.

\section{Populasi dan Sampel}

Populasi yang diambil untuk penelitian ini adalah pengguna marketplace Shopee di Provinsi Jawa Barat, dengan jumlah sampel sebanyak 100 orang sampel yang diambil dengan menggunakan teknik non probability sampling dengan sampling kuota.

\section{Teknik Pengumpulan Data}

Pengumpulan data dilakukan dengan menggunakan teknik studi pustaka, kuisioner, dan skala likert yang digunakan untuk mengukur sikap (attitude statement), melalui pernyataan sikap terhadap suatu objek pertanyaan. Pada penelitian ini, peneliti membuat 22 butir pertanyaan berdasarkan variabel $\mathrm{X}$ dan $\mathrm{Y}$.

\section{Teknik Analisa Data}

Untuk menjawab masalah yang telah diidentifikasi setelah data dan informasi terkumpul kemudian dilakukan analisis secara kualitatif dan kuantitatif berdasarkan teori yang telah diuraikan sebelumnya, sebagai berikut:

1)Metode analisis data deskriptif dari hasil studi Pustaka.

2)Teknik uji regresi linear sederhana.

3)Metode pengambilan saran-saran dari hasil identifikasi masalah pertama, dan kedua.

\section{HASIL PENELITIAN DAN PEMBAHASAN}

1. Berdasarkan hasil dari kajian Pustaka, diketahui bahwa ada tiga strategi digital marketing yang dilakukan oleh marketplace Shopee, yaitu:

1) Teknik pemasaran yang sesuai dengan trend. Dengan mengikuti trend yang sedang viral di masyarakat Shopee dapat dengan mudah mendapatkan perhatian konsumen. 
2) Memaksimalkan media digital sebagai tempat promosi, seperti menggunakan tujuh strategi digital marketing.

3) Menerapkan Bauran Pemasaran Digital 4C, yaitu co-creation, currency, communal activation, dan conversation.

2. Untuk melihat pengaruh strategi digital marketing terhadap minat beli konsumen pada marketplace Shopee di era pandemic Covid-19 dilakukan beberapa uji sebagai berikut:

\section{a. Uji Instrumen Data}

Uji Validitas

Variabel Strategi Digital Marketing (X) dan variabel Minat Beli Konsumen (Y) yang terdiri dari masing-masing 11 pernyataan diperoleh nilai rhitung > rtabel $(0,1966)$ sehingga dapat disimpulkan bahwa semua pernyataan variabel dalam penelitian ini dinyatakan "Valid".

\section{Uji Reliabilitas}

Berdasarkan hasil perhitungan diperoleh hasil Cronbach's Alpha variabel X adalah 0,930>0,60 dan variabel $\mathrm{Y}$ adalah 0,963 > 0,60 dari masingmasing 11 item pernyataan maka dapat ditarik kesimpulan bahwa dari setiap pernyataan reliabel atau stabil dari waktu ke waktu.

\section{b. Uji Asumsi Klasik}

Uji Normalitas

Pengujian normalitas data dapat menggunakan uji Kolmogorov-smirnov. Suatu data dikatakan normal jika memiliki nilai signifikansi $>0,05$. Berdasarkan hasil uji normalitas penelitian memiliki nilai signifikansi 0,200 >0,05, maka dapat disimpulkan bahwa data berdistribusi normal.

\section{Uji Heteroskedastisitas}

Deteksi gejala dilakukan dengan menggunakan teknik Uji Glejser, suatu data dikatakan tidak terjadi heteroskedastisitas jika nilai signifikansi lebih dari 0,05. Berdasarkan hasil pengujian diperoleh nilai signifikansi untuk variabel Strategi Digital Marketing sebesar 0,106 dan menunjukan bahwa nilai variabel bebas tersebut lebih besar dari 0,05 yang artinya tidak terjadi masalah heteroskedastisitas.

\section{c. Uji T Parsial}

Berdasarkan hasil pengujian diketahui nilai signifikansi variabel strategi digital marketing sebesar 0,001 lebih kecil dari 0,05, artinya variable strategi digital marketing berpengaruh signifikan terhadap minat beli konsumen. Kemudian dapat diketahui pula bahwa nilai koefisien regresi variabel strategi digital marketing adalah sebesar 0,767 bernilai positif, sehingga dapat dikatakan bahwa strategi digital marketing berpengaruh positif terhadap minat beli konsumen. Pengaruh positif memiliki arti bahwa semakin meningkatnya strategi digital marketing maka semakin meningkat pula minat beli konsumen.

\section{d. Analisis Korelasi Variabel X dan Y}

Diketahui bahwa hasil korelasi (r) antara variabel X (Digital Marketing) dengan variabel Y (Minat Beli Konsumen) yaitu sebesar 0,718. Artinya terdapat hubungan positif antara digital marketing dengan minat beli konsumen. Tingkat keeratan berdasarkan aturan Guilford adalah erat yaitu $\pm 0.70 \leq p \geq 0.90$.

\section{Koefisien Determinasi Variabel X dan Y}

Hasil menunjukan bahwa koefisien determinasi variabel strategi digital marketing sebesar 0,515 atau $51,50 \%$, artinya variabel digital marketing mempengaruhi variabel minat beli konsumen sebesar 51,50\% dan sisanya 48,50\% dipengaruhi oleh faktor lain yang tidak diteliti dalam penelitian ini seperti kebutuhan, produk berkualitas, dan sebagainya.

4. Berdasarkan hasil dari pembahasan diatas, diketahui bahwa ada tiga strategi yang dapat dilakukan untuk meningkatkan strategi digital marketing Shopee, yaitu:

Menetapkan strategi pemasaran STP pada bisnis digital, yaitu Segmenting, Positioning, dan Targeting yang merupakan suatu proses menyeluruh dari mulai perencanaan hingga gambaran secara terperinci pelaksanaannya pada kurun waktu tertentu.

Mempertahankan keunggulan yang tidak dimiliki kompetitor, sebagai contoh dari laporan DailySocial, Shopee mendapatkan peringkat yang tinggi dalam hal produk murah dan biaya pengiriman gratis.

Menjaga skema bisnis sebagai e-commerce melalui komunikasi yang terjalin agar keberadaan e-commerce seperti ini dapat menguntungkan semua pihak yang terlibat seperti penyedia jasa marketplace, seller, hingga konsumen individu. 


\section{SIMPULANDAN SARAN}

\section{Simpulan}

Berdasarkan hasil dari penelitian diketahui bahwa terdapat 3 strategi digital marketing yang dilakukan oleh Shopee yaitu teknik pemasaran yang sesuai dengan trend, memaksimalkan media digital sebagai tempat promosi, dan menerapkan bauran pemasaran $4 \mathrm{C}$.

Hasil korelasi (r) antara variabel $\mathrm{X}$ (Digital Marketing) dengan variabel Y (Minat Beli Konsumen) yaitu sebesar 0,718. Artinya terdapat hubungan positif antara digital marketing dengan minat beli konsumen. Selanjutnya diketahui koefisien determinasi variabel strategi digital marketing sebesar 0,515 atau $51,50 \%$, artinya variabel digital marketing mempengaruhi variabel minat beli konsumen sebesar 51,50\% dan sisanya

$48,50 \%$ dipengaruhi oleh faktor lain yang tidak diteliti dalam penelitian ini seperti kebutuhan, produk berkualitas, dan sebagainya.

Berdasarkan hasil tersebut dapat diidentifikasi bahwa ada tiga hal yang dapat dilakukan untuk meningkatkan strategi digital marketing Shopee yaitu menetapkan strategi pemasaran STP pada bisnis digital, mempertahankan keunggulan yang tidak dimiliki kompetitor, dan menjaga skema bisnis sebagai e-commerce.

\section{Saran}

Antusiasme masyarakat dalam menggunakan Shopee khususnya saat pandemi yang menyebabkan peningkatan transaksi haruslah dikontrol oleh Shopee dengan baik, sehingga memperkecil kemungkinan adanya resiko excess demand, sehingga pelayanan yang diberikan oleh Shopee terhadap konsumen senantiasa stabil demi tercapainya kepuasan konsumen.

Besarnya pengaruh digital marketing dalam meningkatkan minat beli konsumen di era pandemi Covid-19 haruslah dimanfaatkan dengan baik, salah satunya adalah dengan terus menciptakan inovasiinovasi khususnya dibidang marketing dengan menggunakan platform digital untuk terus meningkatkan peluang penjualan.

\section{DAFTAR PUSTAKA}

Assael, H. 2002. Consumer Behavior and Marketing Action. Boston: PWS-Kent Publishing Company

Abdurachman, Ujianto. 2004. Analisis FaktorFaktor yang Menimbulkan Kecenderungan Minat Beli Konsumen Sarung (Studi Perilaku Konsumen Sarung di Jawa Timur), Jurnal Manajemen \& Kewirausahaan Vol. 6, No. 1, Maret 2004

Caviello, Milley, Marcolin. 2001. Manajemen Pemasaran Dasar, Konsep dan Strategi. Jakarta: PT. Raja Grafindo

Dave Chaffey, Fiona Ellis-Chadwick. 2019. Digital Marketing Strategy, Implementation, and Practice. Inggris

Djaslim, Saladin Yevis Marty Oesman. (2002). Intisari Pemasaran dan Unsur-Unsur Pemasaran. Bandung: Linda Karya

Durianto, Liana. 2004. Analisis Efektivitas Iklan Televisi Softener Soft \& Fresh di Jakarta dan Sekitarnya dengan Menggunakan Consumer Decision Model. Jurnal Ekonomi Perusahaan, Vol.11 (no.1): 35-55

Ferdinand, Augusty. 2002. Pengembangan Minat Beli Merek Ekstensi. Semarang: Universitas Diponegoro

Heidrick, Strugless. 2009. The Adaption of Digital Marketing in Financial. Services Under Crisis

Keller, Kevin Lane Keller. 1998. Strategic Bbrands Management: Building, Measuring, and Managing Brand Equity. New Jersey: Prentice Hall Inc

Kinnear, Thomas C dan Taylor, James R. 1995. Riset Pemasaran. Alih Bahasa. Yohanna Lamarto; Jilid II. Erlangga. Jakarta.

Kotler dan Keller. 2009. Manajemen Pemasaran. Jakarta: Erlangga

Kotler. 2000. Manajemen Pemasaran edisi Milenium. Jakarta: Prenhallindo 
372 Coopetition, Vol 12, Nomor XII, November 2021, (E-ISSN : 2615-4978, P-ISSN : 2086-4620)

Kotler, Armstrong, Gray. 2008. Prinsip-prinsip Pemasaran, Jilid I. Erlangga: Jakarta

Kotler, Hermawan Kartajaya, Iwan Setiawan. 2020. Marketing 4.0 Bergerak Dari Tradisional Ke Digital. Jakarta: Gramedia

Kotler, Kevin Lane Keller. 2009. Manajemen Pemasaran Jilid I Edisi 13. Jakarta: Erlangga

Mekari. Pengertian, Kelebihan, Jenis dan Strategi Digital Marketing. A Jurnal, Vol.7 (no.4)

Tjiptono, Fandy. 2006. Strategi Pemasaran. Yogyakarta: Andi.Offset.

Sugiono. 2013. Metode Penelitian Kuantitatif, Kualitatif, dan $R \& D$. Jakarta: CV. Alfabeta. 